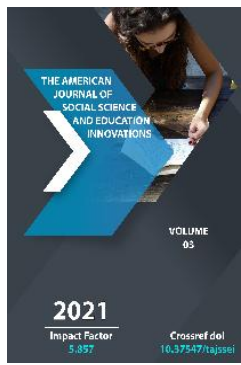

\section{Biogeographic Studies Conducted In The Fergana Valley}

\author{
Abdusamad Abdumalikovich Hamidov \\ Senior Lecturer, Ph.D. Fergana State University, Uzbekistan \\ Khurshid Bakhtiyorovich Khalilov \\ Methodist Of The Fergana Regional Institute For Retraining And Advanced Training, \\ Uzbekistan
}

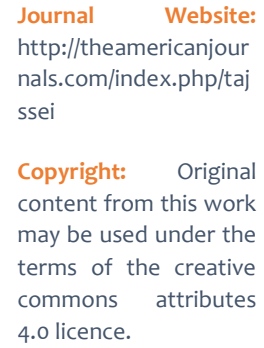

Copyright: Original content from this work may be used under the terms of the creative commons attributes 4.0 licence.

\title{
ABSTRACT
}

The article discusses the study of flora, one of the components of nature in the Fergana Valley, based on its stage of development in space and time. The article also describes the scientific results of research on the flora of the Fergana Valley and adjacent areas from 1917 to 1954.g of scientific research in the Fergana valley.

\section{KEYWORDS}

Fergana valley, landscape-geographical, soil science, geobotany, ecological, florogenetic, phytocenological methods, flora, ecological-phytocenological, vegetation, soil-botanical, soil-soil, forest-ameliorative activities, botanical expedition.

\section{INTRODUCTION}

Scientists of the Central Asian State University, founded in 1920, and later Tashkent State University, made a worthy contribution to the vegetation of the Fergana Valley and adjacent areas from 1917 to 1945.Extensive soil-botanical, soilgeographical research conducted by the Institute of Soil Science and Geobotany under SAGU was characterized by a wide range of landscape-geographical characteristics in its scientific direction. (Rahimbekov R.U., 1970).
N.A. Dimo, who supervised the scientific work of the institute, wrote: "The main idea of the scientific research in the establishment of the Institute of Soil Science and Geobotany is the interpretation of the formation of separate parts of the earth's surface through the red thread. Soil and soil-soil are both habitats and regenerators for vegetation and vegetation cover, and an indicator of this environment "[1]. 


\section{THE MAIN FINDINGS AND RESULTS}

The development of complex soil-botanical and soil-geographical work of the Institute consisted of research directly related to the issues of various sectors of the economy. In particular, special methods of botanical and geographical research have been developed and put into practice, ie; Ecological methods (R.I.Abolin, E.P.Korovin), Floristic-florogenetic method (M.V.Kultiasov, A.I.Vvedensky, M.G.Popov) and phytocenological method (R.I.Abolin, V .P.Drobov, E.P.Korovin).

The main expedition and partially stationary studies in the Fergana Valley and adjacent areas were aimed at studying plants, description of meadows, identification of hayfields, beneficial and harmful plant species, study of weeds in agricultural lands.

The valuable scientific results of the expeditionary research conducted by the Central Asian State University in the Fergana Valley and adjacent areas are mainly reflected in the following:

In 1924, VP Drobov studied the plants of the western part of the Fergana Valley. The research covered the Karakchikum district, the areas on the right and left banks of the Syrdarya, the basins of the Isfara River. The main purpose of the study was to study moving sands and identify forest reclamation measures.

V.P. Drobov distinguishes 3 types of places in the study area:

1. Sandy.

2. Soil.

3. Determines the norm of formation of rocky desert and 5 main sands;

1. Barkhans in motion,

2. Stationary sandy rows,

3. Dunes,

4. Stationary sandy borders.

5. Sandy hills.
A comparison of the vegetation on the right and left banks of the Syrdarya showed that the left bank was composed mainly of grasses and the right bank was composed mainly of shrubs.

According to V.P. Drobov, the main reason for this is the strong salinity of the left bank and the consequences of large-scale felling of bushes by the population.

V.P. Drobov pays great attention to the interrelationships of the 3 main formations of plants;

1) Distribution in areas covered with lyoss.

2) Distribution in sand deposits and strongly saline sands.

3) Distribution in eol collections.

In 1921, under the leadership of N.A. Dimo, the Institute of Soil Science and Geobotany began to study the geographical distribution of soils and plants along the longitudinal and latitudinal zones in the Fergana Valley and adjacent areas.

During these years, 8 soil-botanical, soilgeographical expeditions worked on the territory of Uzbekistan. The soil-botanical, soilgeographical research in Yazyavan (35,000 ha) and Dalvarzin $(80,000 \mathrm{ha})$ was personally supervised by N.A. Dimo.

In the summer of 1925, A.V. Blagoveshensky was engaged in physiological research in the desert areas of the left bank of the Fergana Valley, as well as the collection of samples from flora (Blagoveshensky. 1926).

The results of research on the physiological development of soil, saline and sandy plants are covered in 2 articles by A.V. Blagoveshensky and his students V.A. Bogolyubova, T.A. Chernova and others. (Rozanov.1929). An interesting aspect of this research is that specific issues in the physiology of desert plants have been studied 
in close connection with the ecological status of their habitat (growing).

In 1926-1927, E.P. Korovin and M.V. Kultiasov conducted geobotanical research in the Fergana Valley and the Western Tianshan Mountains in connection with the development of new lands. Based on the results of this research, in 1927 M.V. Kultiasov's article "Highlands of Western Tianshan" was published. In the history of botanical-geographical and ecologicalphytocenological study of the Fergana Valley and adjacent areas, a special place is occupied by the great forerunner of Central Asian plants EP Korovin.

In 1927, this researcher led the Jalal-Abad party of the SAGU expedition. They will study Kyrgyzstan's livestock areas and forage areas. As a result of these studies, 2 scientific results were obtained, which were not very large, but very rich in scientific ideas. One of these has such generalized lines; "Fergana ridge and Bobosh ota, Usuptog uphill cross the clear boundary of 2 floristic regions (Original Mediterranean and Central Asia).

Elements of Mediterranean flora are distributed in the interior of the Fergana Valley, and elements of Central Asian flora are scattered around it. Differences between them can be seen in the flora, landscape and internal ecological analysis of plants in all botanical-geographical complexes.

The botanical-geographical individuality of plants is felt most quickly in the lower regions of the mountains, but it is much more difficult to feel it in the upper parts of the mountains. At the heart of this, of course, lies the different distribution of climatic conditions. The Fergana Valley has a Mediterranean description of the distribution of precipitation. The surrounding parts of the Fergana Valley are modeled on the Central Asian climate. "[2]
According to E.P. Korovin, the classic representative of the formation of broadleaved ores of absolute botanical and geographical interest are the walnut forests collected in the Arslonbob-Qoraungur watershed.

Not only theoretical but also practical conclusions of E.P. Korovin were later developed by specialists in the field of science; .Babushkin and N.A. Kogay $(1964,1965)$ and others.

E.P. Korovin convincingly noted in 1927 that the north-eastern part of the Fergana Valley is typical of the Mediterranean type, as the region has a temperate subtropical climate. An important conclusion to be drawn from this is:

- The Fergana Valley has great potential and application properties for the cultivation of many different types of subtropical crops, because in its northern part there are areas of subtropical regions.

In 1928, A.F. loffe participated in the soilbotanical expedition as part of the Institute of Soil Science and Geobotany. Under the general guidance of AN Rozanov, the researcher is engaged in the study of vegetation in Namangan, Kuyganyor districts and in the lower reaches of Govasay, Chodaksay and Rezaksay. His report on the results of the expedition is kept in manuscript form in the Central Archives of the Republic of Uzbekistan under the number B-251.

By 1928, the expeditions of the Institute of Soil Science and Geobotany were further intensified. This year, the number of organizations served by the institute has also increased.

Results and discussions: Special expeditions have been organized to study the nature of the Fergana Valley in detail. 
Researchers of the Institute A.N. Rozanov, A.I. Mentsi and A.F. loffe conducted research in 3 districts of the Fergana Valley on behalf of the Central Asian Water Management. The study covered 50,000 hectares of land in the Namangan irrigation district.

Soils and plants of Kuyganyor irrigation region of Andijan oblast were studied and surveyed on a 2-scale scale. As a result, the level of suitability for irrigated agriculture was determined.

The study area of the expedition was 160,000 and it included the northern and northeastern left banks of the Fergana Valley. The results of the expedition's botanical research were very good material in writing an essay by A.F. loffen on the plants of the Kuyganyor Irrigation District. This scientific work by A.F. loffe is written in the botanical-geographical direction, in addition to the description of the vegetation cover, it also contains information about the relief, climate and soils.

The essay outlines the role of the geographical distribution of plants: "In addition to these natural factors, one of the features that characterizes the vegetation cover is the impact of very strong human economic activities on nature in this area." [3].

A.F. lofe points out that the destruction and cutting of many plants to burn them turns the hills into barracks as a result of irregular grazing of livestock on sandy hills, and as a result of large areas of land being irrigated, not only vegetation but even irrigated areas change groundwater rising points are also felt. [4].

In the same year, one of the botanical expeditions of the Institute for Water Resources of the Uzbek SSR conducted research in the Uchkurgan district of the former Andijan region. Based on the results of the expedition materials, A.F. Ioffe created a geobotanical sketch of the surveyed area. (loffe, B-299). Disagreeing with the conclusions of SS Neustruev, who studied the region in 1911, A.F. loffe says that the most characteristic plant element in the northeastern part of the Uchkurgan steppe is wormwood. However, SS Neustruev concluded that the vegetation of the region consisted mainly of salt marshes.

According to A.F. Ioffen, the wormwood plant is a completely zonal plant type for all the Uchkurgan steppes.

In the same year (1928) MM Sovetkina was engaged in the study of plants in the Khojand region on the left bank of the Syrdarya. In his work, published in 1929, he describes the area as a natural vegetation, cultivated plant, and weed in the fields.

In 1929, with the complex soil and botanical research of the Institute of Soil Science and Geobotany, the upper part of the right bank of the Syrdarya (M.V. Kultiasov, I.A. Tishchenko), Central Fergana (K.M. Klavdienko, A.A. Mentsi), Akbura-Shahrikhan (D.I.Tarasov, M.M.Abramova and O.I.Yankina), Uchkurgan seed farm, separate irrigation plots (G.I.Olovyanishinikov, G.Ts.Gortsak) and others. However, the scientific results of these studies have not been published in plant maps compiled on a scale of 1: 100,000 and 1: 10,000 [5].

In 1930-1931, under the general leadership of EP Korovin, foreign plants of the Fergana Valley and adjacent areas were studied in "Naiman", "Yusupov Combine", "Uchkurgan" and a number of other state farms. The results of the study were included in the monograph of EP Korovin "Weeds in Central Asian cotton fields and measures to combat them" (1934).

In 1931, VP Melnikov studied the plants of the Fergana Valley and adjacent areas.

\section{CONCLUSION}


In general, the capital work of EP Korovin, published in 1934, entitled "Plants of Central Asia and South Kazakhstan", contains a lot of information about the vegetation of the Fergana Valley and adjacent areas. The play shows important aspects not only of floristic, geobotanical and ecological ideas, but also in the evolution of general geographical ideas. It analyzes the most important zonal, regional and typological laws of the landscape of the region using plants and their ecological conditions.

O.N. Bondarenko (1954) testified that these materials are more complete and accurate than the materials of previous authors. According to him, geobotanical research in the pre-war and war-torn Fergana Valley and adjacent areas was continued by M.V. Kultiasov and A.F. Ioffe.

\section{REFERENCES}

1. N.A.Dimo, Institute of Soil Science and Geobotany SAGU. News of the Institute of Soil Science and Geobotany SAGU.1927, Appendix to the issue.3.Pages.3-4. (Н.А.Димо,Институт почвоведения и геоботаники САГУ. Известия Инс-та почвоведения и геоботаники САГУ.1927, Приложение к выпуску.3.Стр.3-4.)

2. E.P.Korovin.Plant associations of the Fergana Range. Leningrad. 1928.page.61.(Е.П.Коровин.Растительные ассоциации Ферганского хребта. Ленинград. 1928.Стр.61.)

3. loffe A.F. Vegetation of the KuiganYarskregion.UzSSR, TsNSXB, Page-246 (ИоффеА.Ф. РастительностьКуйганЯрскогорайона.УзССР, ЦНСХБ, Б-246)

4. Ioffe A.F. Archive, TsNSXB. B-299, Page.16 (ИоффеА.Ф. Архив, ЦНСХБ. Б-299, Стр.16)

5. Rahimbekov R.U. The role of the Central Asian (Tashkent) State University in the study of the nature of Central Asia.Tashkent. 1970. Pages.100103(Рахимбеков Р.У. Роль Среднеазиатского (Ташкентского)
Государственного Университета в изучении природы Средней Азии. Ташкент. 1970. Стр. 100-103). 